\title{
Backfill mixtures based on industrial waste
}

\author{
Shavkat Rakhimov ${ }^{1 *}$, Uchqun Gaziev, Nilufar Babakulova, and Qunduz Khudoynazarova \\ Tashkent Institute of Architecture and Civil Engineering, Tashkent, Uzbekistan
}

\begin{abstract}
The object of the study is filling mixtures based on waste from the mining, energy, and copper-smelting industries, Portland cement, and superplasticizer. In the course of the study, standardized methods for studying the properties and quality indicators of industrial waste and filling mixtures based on it and mathematical methods for optimizing the compositions of mixtures, statistical methods for analyzing the results of experiments, were used. It has been established that, in terms of their physical and mechanical characteristics, stowing mixtures based on waste are not inferior to mixtures based on natural materials. The mathematical method for planning experiments has revealed the dependences linking strength with the quantitative characteristics of the components of the filling mixture. Based on the established regularities, an optimization model has been developed that minimizes the consumption of the binder and establishes a relationship between the composition and properties of the mixture.
\end{abstract}

\section{Introduction}

An analysis of previous studies has shown that very important positive results have been achieved in improving energy efficiency and creating resource-saving technologies in the production of backfill mixtures for filling mined-out spaces formed during ore mining. However, the analysis of the scientific results obtained on the development of energy and resource-saving technologies involving the use of industrial waste shows that in studies aimed at the development of compositions of effective mixtures, in particular, on the production of filling mixtures based on secondary products and chemical additives, there are insufficiently studied scientific problems, which indicates the need for a deeper study of these issues[1,2].

The desire to increase the extraction of minerals from the subsoil, the creation of more favorable conditions for the separate extraction of multi-grade ores, and underground mining safety predetermined the wide development of the development of deposits by systems with solidifying backfill of the mined-out space.

Introduction In the world of construction and the mining industry, the share of the use of efficient energy-saving technologies is increasing. In particular, in such developed countries of the world as the USA, Germany, Japan, China, Russia, it is all very important to use development systems with laying the worked out space not from natural raw materials, which is a mixture of inert materials with binders, but various wastes and

*Corresponding author: raximov.12081979@mail.ru 
associated products. Industry, primarily mining, fuel-energy, chemical, and metallurgical, ensures their strength and stability. In this regard, special attention is paid to the development of compositions of new building materials, in particular, filling mixtures based on local raw materials and industrial waste and the creation of energy-saving technologies for their production [3].

Analysis of the state of the production of backfill mixtures showed that the use of traditional calcium binders, in particular Portland cement, does not allow obtaining backfill mixtures that fully meet the necessary requirements. The recommended ways to increase their physical and mechanical characteristics, as a rule, are associated with the need for significant overruns of the binder, the use of natural resources, and technological methods that require additional labor and energy consumption $[4,5]$.

In this regard, scientists and material scientists are conducting research to improve the quality of the product and reduce the cost of using local raw materials and various industrial waste to produce backfill mixtures to fill the mined-out area.

There is a tendency of increasing use for the preparation of hardening backfill as a binder and fillers of various wastes and by-products of the industry, primarily mining, fuel and energy, and chemicals.

Waste management is beneficial from both economic and social points of view. So, in comparison with the use of natural raw materials, the costs of exploration, construction, and operation of quarries are excluded, the costs of fuel, energy, and transport are significantly reduced, the cost of mined ore and finished products is reduced, the land occupied by dumps is reduced, the raw material base of the construction industry expands materials, as well as issues of environmental protection from pollution [6, 7].

Earlier, for the plant, the compositions of filling mixtures were developed using fly ash from the Angren State District Power Plant, waste from the marble quarry "Kora-Khona," as well as mixtures based on a slag-alkaline binder, for which a patent of the Republic of Uzbekistan was obtained and regulatory documents were prepared [8, 9 and 10$]$.

At present, in connection with the completion of the marble quarry, problems have arisen to provide the combine with raw materials to prepare filling mixtures.

To develop new optimal compositions of filling mixtures, the following types of waste generated at the plant itself were selected and studied:

- Waste rock sand obtained at the crushing plant at the Kauldy mine after the extraction of minerals. The limiting sand size is $5 \mathrm{~mm}$;

- marble processing waste generated from the activities of the marble workshop of the combine. This additive is used as a plasticizer and reduces the abrasive properties of waste rock sand;

- slags of copper-smelting production in the form of finely ground powder.

Of the variety of metallurgical slags, copper smelting and nickel slags are of no less interest for construction and the production of building materials. A general view of copper smelting waste is shown in Figure 1. 

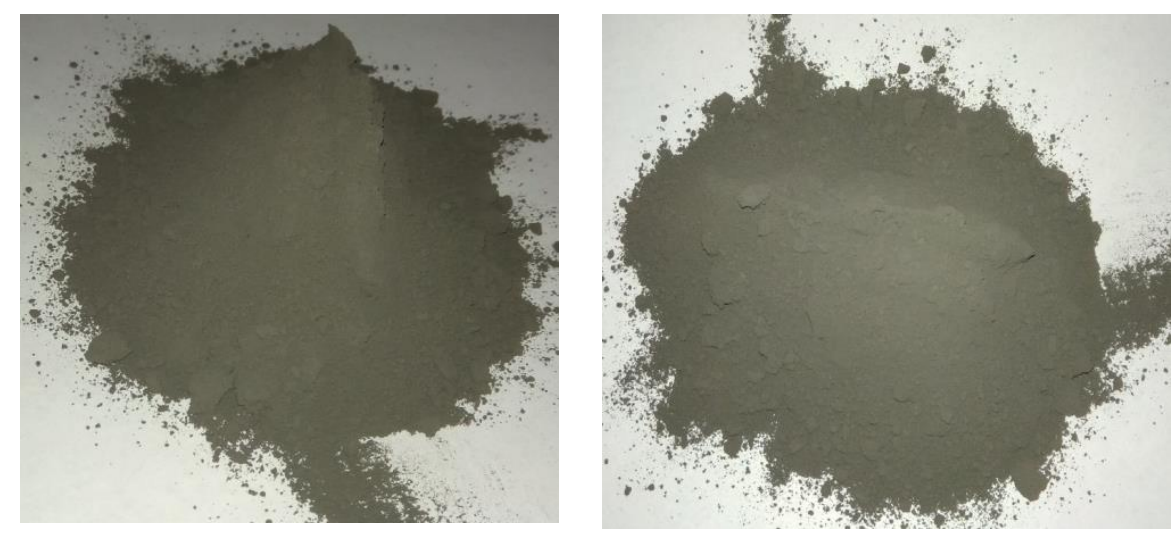

Fig.1. General view of copper smelting waste

It should be noted that the above wastes do not require additional technological processing and are used in their natural form.

\section{Methods}

A mathematical model has been developed that expresses the relationship between the strength and the quantitative ratio of the constituent filling mixtures [3].

For this purpose, mathematical models have been developed for obtaining filling mixtures with predetermined properties based on correlation and regression analysis.

Variable factors:

$\mathrm{x}_{1}$ - portland cement consumption in filling mixture, $\mathrm{kg}$;

$\mathrm{x}_{2}$ - ash consumption in filling mixture, $\mathrm{kg}$;

$\mathrm{x}_{3}$ - superplasticizer consumption FREM C-3, $\mathrm{kg}$

The optimization process is described by a second-order polynomial, for which an orthogonal plan of the full factorial experiment was chosen (Table 1).

$$
\begin{aligned}
& Y=a_{0}+a_{1} x_{1}+a_{2} x_{2}+a_{3} x_{3}-a_{1,2} x_{1} x_{2}+a_{1,3} x_{1} x_{3}+ \\
& +a_{2,3} x_{2} x_{3}+a_{1,2,3} x_{1} x_{2} x_{3}+a_{1,1} x_{1}^{2}+a_{2,2} x_{2}^{2}-a_{3,3} x_{3}^{2}
\end{aligned}
$$

The equation that describes the optimization process is:

Table 1. Orthogonal plan of the full factorial experiment

\begin{tabular}{|c|c|c|c|}
\hline Initial data of the planned experiment & $\mathrm{x}_{1}$ & $\mathrm{x}_{2}$ & $\mathrm{x}_{3}$ \\
\hline Center of Experiment & 120 & 30 & 3 \\
\hline Variation interval & 40 & 10 & 1 \\
\hline Upper level $\left(\mathrm{x}_{\mathrm{i}}=+1\right)$ & 160 & 40 & 4 \\
\hline Lower level $\left(\mathrm{x}_{\mathrm{i}}=-1\right)$ & 80 & 20 & 2 \\
\hline
\end{tabular}

The optimization was carried out according to the orthogonal plan of the full factorial experiment; therefore, the influence of the analyzed factors on the strength of the filling mixture can be represented as a second-order polynomial.

The statistical model of the strength of the filling mixture has the form: 


$$
\begin{aligned}
& Y=5.467+1.94 x_{1}+0.353 x_{2}+0.297 x_{3}- \\
& 0.183 x_{1} x_{2}+0.105 x_{1} x_{3}+0.002 x_{2} x_{3}+0.104 x_{1} x_{2} x_{3}+ \\
& +0.842 x_{1}^{2}+0.015 x_{2}^{2}-0.116 x_{3}^{2}
\end{aligned}
$$

where $\mathrm{Y}=\mathrm{R}_{28 \text { days }}$ is the compressive strength (28 days) of the filling mixture, MPa.

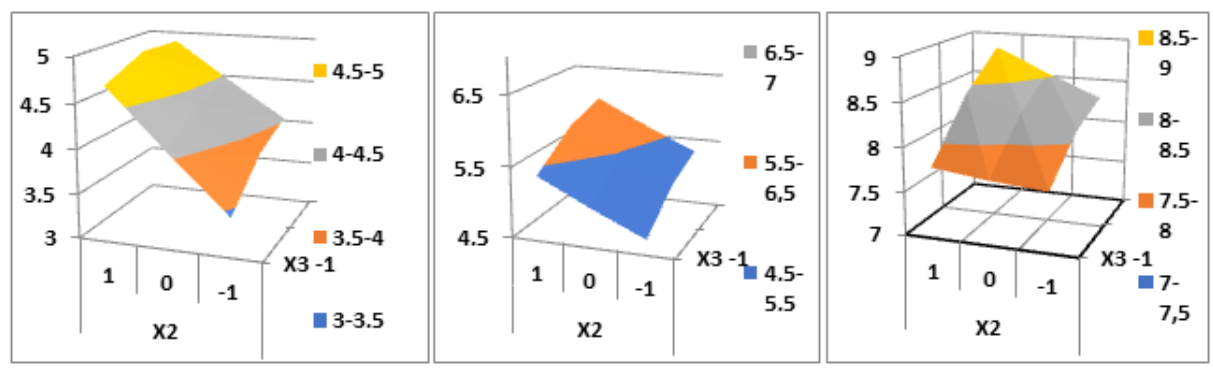

Fig.2. The plot of the strength of the filling mixture on the amount of portland cement $\left(\mathrm{x}_{1}\right)$, ash $\left(\mathrm{x}_{2}\right)$ and additives $\left(\mathrm{x}_{3}\right)$ : a) $\mathrm{x}_{1}=-1$; $\left.\mathrm{b}\right) \mathrm{x}_{1}=0$; c) $\mathrm{x}_{1}=1$

To identify the processes of structure formation in cement and ash-cement compositions, we studied samples that were solid for 28 days in a normal hardening chamber at a temperature of $20{ }^{\circ} \mathrm{C}$ and $95 \%$ air humidity.

The hardening of the filling mixture with fly ash is caused by the hydration of calcium oxide, anhydride, and the interaction of these products with the glass of ash hydrolyzed in an alkaline medium and with an amorphous clayey substance.

It is possible to increase the number of neoplasms of hydration products and thus increase the strength of the filling mass, possibly with the introduction of ordinary portland cement to the mixture on fly ash. Thus, during hardening of the filling mixture under normal conditions, the hydration of calcium oxide $(\mathrm{CaO})$ ash, the hydration of Portland cement minerals, the interaction of calcium hydroxide with amorphous clayey ash, and carbonization of the cement composition occur.

Due to the high content of calcium oxide $(\mathrm{CaO})$ in the initial ash of dry selection, the complete absorption of $\mathrm{Ca}(\mathrm{OH})_{2}$ during hardening is not achieved, which is a reserve for the growth of the filling mixture strength over time. This is confirmed by the change in the strength of the filling mixture due to testing samples after 7, 28, and 60 days.

The development of optimal compositions of filling mixtures was carried out using a mathematical method of planning an experiment, verified by a computational and experimental method, with further refinement in the manufacture of test mixes in laboratory conditions with testing the actual rheological and physical-mechanical characteristics of filling mixtures and solidified samples. The test procedure for samples-cubes of filling mixtures based on waste with face sizes of 7 and $10 \mathrm{~cm}$ corresponded to the requirements of regulatory documents for conventional mortars. The test period for the cube samples was 28 days.

Waste of a marble quarry after processing on the classifier had a granulometric composition presented in Table 2. The same table shows the grain size composition of rock sand. 
Table 2. Granulometric composition of waste from a marble quarry and rock sand

\begin{tabular}{|c|c|c|c|c|c|c|c|c|c|}
\hline \multirow{2}{*}{ Names } & \multicolumn{6}{|c|}{ Private balances on sieves, } & $\begin{array}{c}\text { Passed } \\
\text { through a } \\
\text { sieve 0.14 }\end{array}$ & $\begin{array}{c}\text { The amount } \\
\text { of clay and } \\
\text { dust particles }\end{array}$ & $\begin{array}{c}\text { Size } \\
\text { module }\end{array}$ \\
\hline $\begin{array}{c}\text { Waste from a } \\
\text { marble quarry }\end{array}$ & 0.15 & 15 & 15 & 25 & 16.5 & 18.5 & 9.5 & $0.7-0.9$ & $1.7-1.9$ \\
\hline Mountain sand & 1.5 & 12.0 & 9.0 & 19.5 & 15.5 & 14.0 & 28.5 & 1.5 & $1.0-1.2$ \\
\hline
\end{tabular}

\section{Results and Discussion}

The tests' results for filling mixtures using waste rock, marble processing waste, and copper smelting slags are shown in Tables 3, 4, and 5.

Table 3. Optimal composition of filling mixtures using waste rock sand for the Kauldy mine

\begin{tabular}{|c|c|c|c|c|c|}
\hline \multirow{2}{*}{$\begin{array}{c}\text { Train } \\
\text { numbers }\end{array}$} & \multicolumn{3}{|c|}{ Amount of materials per $1 \mathrm{~m}^{3}$ of mixture, $\mathrm{kg}$} & \multirow{2}{*}{$\begin{array}{c}\text { Mix } \\
\text { mobility, } \\
\mathrm{cm}\end{array}$} & \multirow{2}{*}{$\begin{array}{c}\text { Average } \\
\text { compressive } \\
\text { strength, MPa }\end{array}$} \\
\hline & $\begin{array}{l}\text { Portland cement } \\
\text { grade } 400\end{array}$ & $\begin{array}{c}\text { Wasteland sand } \\
5 \mathrm{~mm} \text { or less }\end{array}$ & Water & & \\
\hline $\mathrm{I}$ & 100 & 1400 & 280 & $14-16$ & 2.5 \\
\hline II & 150 & 1400 & 280 & 14-16 & 4.0 \\
\hline III & 200 & 1400 & 280 & $14-16$ & 8.8 \\
\hline IV & 250 & 1400 & 280 & $14-16$ & 9.7 \\
\hline V & 300 & 1400 & 280 & $14-16$ & 13.5 \\
\hline
\end{tabular}

Table 4. Optimal compositions of filling mixtures using waste rock sand and marble processing waste for the Kauldy mine

\begin{tabular}{|c|c|c|c|c|c|c|}
\hline \multirow{2}{*}{$\begin{array}{c}\text { Train } \\
\text { numbers }\end{array}$} & \multicolumn{4}{|c|}{ Amount of materials per $1 \mathrm{~m}^{3}$ of mixture, $\mathrm{kg}$} & $\begin{array}{c}\text { Mix } \\
\text { mobility, } \\
\mathrm{cm}\end{array}$ & $\begin{array}{c}\text { Average } \\
\text { compressive } \\
\text { strength, MPa }\end{array}$ \\
\hline grade 400 & 100 & $\begin{array}{c}\text { Wasteland } \\
\text { sand } \\
\text { 5mm or less }\end{array}$ & $\begin{array}{c}\text { Waste from } \\
\text { marble } \\
\text { processing }\end{array}$ & Water & & \\
\hline II & 150 & 1000 & 400 & 300 & $14-16$ & 1.0 \\
\hline III & 200 & 1000 & 400 & 300 & $14-16$ & 1.5 \\
\hline IV & 250 & 1000 & 400 & 300 & $14-16$ & 6.0 \\
\hline V & 300 & 1000 & 400 & 300 & $14-16$ & 8.1 \\
\hline
\end{tabular}




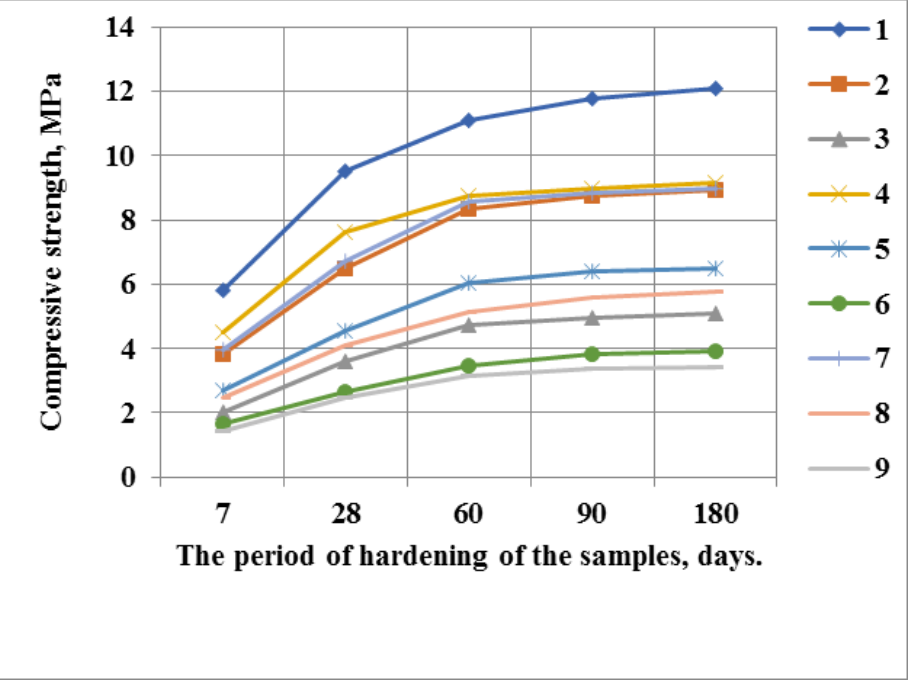

Fig.3. Strength characteristics of filling mixtures of optimal composition: 1 is control sample, cement-200 kg; 2 is control sample, cement- $150 \mathrm{~kg} ; 3$ is control sample, cement- $100 \mathrm{~kg}$; 4 is cement- $160 \mathrm{~kg}$, fly ash- $40 \mathrm{~kg}$; 5 is cement- $120 \mathrm{~kg}$, fly ash- $30 \mathrm{~kg}$; 6 is cement- $80 \mathrm{~kg}$, fly ash-20 kg; 7 is cement- $160 \mathrm{~kg}$, slag- $40 \mathrm{~kg}$; 8 is cement- $120 \mathrm{~kg}$, slag- $30 \mathrm{~kg} ; 9$ is cement $-80 \mathrm{~kg}$, slag- $20 \mathrm{~kg}$

Table 5. Optimal compositions and physicomechanical properties of filling mixtures based on superplasticizer

\begin{tabular}{|c|c|c|c|c|c|c|c|c|c|c|c|c|}
\hline \multirow{2}{*}{ 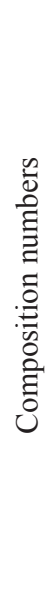 } & \multicolumn{7}{|c|}{ Amount of materials per $1 \mathrm{~m}^{3}$ of mixture, $\mathrm{kg}$} & \multirow{2}{*}{ 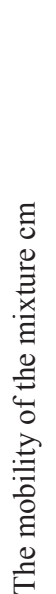 } & \multirow{2}{*}{ 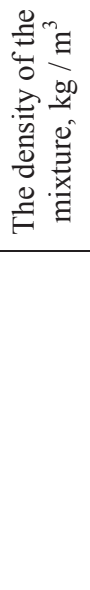 } & \multicolumn{3}{|c|}{$\begin{array}{l}\text { Average compressive } \\
\text { strength, } \\
\mathrm{MPa} \text { (in a day) }\end{array}$} \\
\hline & 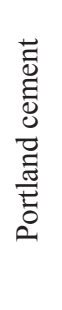 & $\begin{array}{l}\frac{1}{\sqrt{n}} \\
\frac{\vec{x}}{1}\end{array}$ & 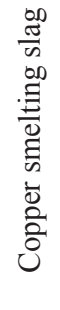 & 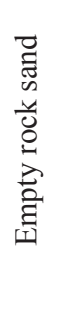 & 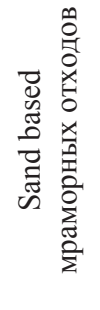 & $\frac{\overline{0}}{\bar{\pi}}$ & 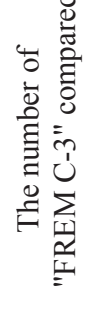 & & & 7 & 28 & 60 \\
\hline 1 & 160 & 40 & - & 1200 & 400 & 242 & 4.0 & \multirow{12}{*}{$\begin{array}{l}\stackrel{7}{I} \\
\beth\end{array}$} & 1845 & 5.28 & 8.94 & 10.85 \\
\hline 2 & 128 & 32 & - & 1200 & 400 & 238 & 3.2 & & 1804 & 3.46 & 6.18 & 9.22 \\
\hline 3 & 120 & 30 & - & 1200 & 400 & 236 & 3.0 & & 1793 & 3.36 & 5.56 & 7.44 \\
\hline 4 & 96 & 24 & - & 1200 & 400 & 230 & 2.4 & & 1762 & 2.38 & 4.84 & 6.65 \\
\hline 5 & 80 & 20 & - & 1200 & 400 & 226 & 2.0 & & 1738 & 2.15 & 3.42 & 4.32 \\
\hline 6 & 64 & 16 & - & 1200 & 400 & 222 & 1.6 & & 1719 & 1.13 & 1.87 & 2.47 \\
\hline 7 & 160 & - & 40 & 1200 & 400 & 238 & 4.0 & & 1838 & 5.16 & 8.16 & 10.28 \\
\hline 8 & 128 & - & 32 & 1200 & 400 & 234 & 3.2 & & 1802 & 3.29 & 5.86 & 8.96 \\
\hline 9 & 120 & - & 30 & 1200 & 400 & 230 & 3.0 & & 1782 & 3.18 & 5.29 & 6.45 \\
\hline 10 & 96 & - & 24 & 1200 & 400 & 228 & 2.4 & & 1762 & 2.16 & 4.26 & 6.21 \\
\hline 11 & 80 & - & 20 & 1200 & 400 & 224 & 2.0 & & 1733 & 1.95 & 3.17 & 3.94 \\
\hline 12 & 64 & - & 16 & 1200 & 400 & 218 & 1.6 & & 1710 & 1.06 & 1.79 & 2.38 \\
\hline
\end{tabular}


The mathematical method for planning experiments has revealed the dependences linking strength with the quantitative characteristics of the components of the filling mixture. Based on the established regularities, an optimization model has been developed that minimizes the consumption of the binder and establishes a relationship between the composition and properties of the mixture. As a result of its use, optimal compositions of 28 daily strength from 1.79 to $8.94 \mathrm{MPa}$ and a density of $1710-1845 \mathrm{~kg} / \mathrm{m}^{3}$ were proposed for compositions based on "cement-ash-fly-away-superplasticizer" and "cement-coppersmelting slag-superplasticizer."

The influence of the dosage of the additive of the superplasticizer "FREM C-3" on the properties of the filling mixture was revealed, the rational content of the mineral binder was determined $-20 \%$ and the chemical additive $-2 \%$ of the weight of the binder. As a result of the superplasticizing effect of the additive in such an amount, the water demand of the filling mixture of the optimal composition decreased by $10-12 \%$, the mobility of the mixture increased from P1 to P5, and the compressive strength (28 days) increased by an average of $20-25 \%$ in comparison with the control samples without additives, the consumption of cement from the standard strength of the filling mixture has decreased by $20 \%$.

When developing the technology for laying filling mixtures into the goaf, two schemes for the construction of artificial massifs were selected and tested:

- erection of artificial massifs using a homogeneous filling with a multi-strength (twothree-layer) filling mixture;

- erection of artificial massifs using a combined (rock-hardening) bookmark.

The essence of the technology for the construction of a multi-strength filling array is as follows. In the treatment chambers (the shaft of the mine), the lower part is initially laid to a height of $1.5-3.0 \mathrm{~m}$ with the composition of the filling mixture, which ensures the standard strength of up to $1.0 \mathrm{MPa}$, in the last turn (the third layer), the upper layer is initially laid at the height of at least $0.5 \mathrm{~m}$ composition, providing standard strength of 3-4.5 MPa. On average, the porosity of the filling mixture is $18-21 \%$. The density of the hardening fill was determined by weighing standard cube-shaped specimens with a face size of 7 and $10 \mathrm{~cm}$. It ranged from $1750 \mathrm{~kg} / \mathrm{m}^{3}$ to $1830 \mathrm{~kg} / \mathrm{m}^{3}[8,11,12]$.

\section{Conclusions}

Analysis of the data obtained allows us to conclude the advisability of further research and use of the plant's waste for filling mixtures since this expands the range of waste used, reduces the cost of mined ore and finished products, increases the strength indicators of filling mixtures, and also improves the environmental situation in the region by eliminating dumps.

The possibility of obtaining backfill mixtures with binding compositions using fly ash and slag from the copper smelter was confirmed. At the same time, the processes of the structure of education in the studied compositions provide the formation of tight and durable contacts due to the implementation of the properties of all the components of the system, ensuring not only their physical but also chemical interaction.

The dependence of the shrinkage of the filling mixture on its age was established that by the 7th day of hardening, the shrinkage intensified, and on the 14th and 28th day of hardening, the shrinkage slowed down and stabilized.

The influence of fly ash on the heat release during hardening of filling mixtures was revealed. The amount of heat emission decreased due to an increase in the quantity of fly ash and a decrease in the hydraulic activity of cement. In our experiments, the heat release of Portland cement decreased more significantly when $20 \%$ was replaced with fly ash. 
It was established that during hardening in water and a humid environment, the strength of samples on Portland cement with the addition of $20 \%$ fly ash and $2 \%$ superplasticizer continuously increases; this is due to the active interaction of fly ash with $\mathrm{Ca}(\mathrm{OH})_{2}$. The results of our research show that composite binders based on fly ash and copper-smelting slag increase the water resistance and moisture resistance of filling mixtures.

The established coefficient of resistance of the investigated compositions of filling mixtures in various aggressive environments characterizes their sufficient resistance and durability. The administration of the «FREM C-3» superplasticizer mixtures also makes it possible to increase the resistance of filling mixtures in aggressive environments.

Due to its scientific and practical novelty and usefulness, this work makes a certain contribution to the development of the theory and practice of creating progressive building materials that give a significant economic effect.

The calculation of technical and economic efficiency is carried out by the traditional method. This economic efficiency considers a decrease in the amount of cement, an increase in the strength of the mixture, and the effect of using the mixture in the worked out mountain space.

The scientific and technical level of the study is characterized by the patent of the Agency for Intellectual Property of the Republic of Uzbekistan IAP 06006 and IAP 06046 [13-15].

\section{References}

1. Yu.M. Bajenov, Texnologiya betona. Uchebnik, M.: Izd-vo ASV, Russia. (2011)

2. M. Neville, Properties of concrete, 5th Edition, Pearson Education Limited, London, (2011).

3. Kh. Kamilov, A. Zaitov, A. Tulaganov, On a formula finding fractal dimension, Archives of Materials Science and Engineering 104 (1) pp.19-22. DOI: https://doi.org/10.5604/01.3001.0014.3865. (2020)

4. A.A. Mukhamedbaev, Investigation of the effect of the time of mechanical activation on the properties of a multicomponent binder, Bulletin of the Perm National Research Polytechnic University, Construction and Architecture 9 (3) pp 121-129. DOI: https://doi.org/10.15593/2224-9826/2018.3.12. (2018).

5. Rakhimov Sh.T., Gaziev U.A., Eshbayeva F.R., Water and air resistance of filling mixtures and the influence of aggressive media on their durability, International Journal on Orange Technologies 2, (11) pp. 26-29. DOI: https://doi.org/10.31149/2224-9826/ijot.v20.11.857. (2020)

6. V.I. Solomatov, V.N. Virovoy, Fizicheskie osobennosti formirovaniya strukturi kompozitsionnix stroitelnix materialov, Izvestiya VUZov. Stroitelstvo i arxitektura 8 pp. 48-52, Russia, (1984)

7. Bertolini M.S., Campos C.I., Souza A.M., Panzera T.H., Christoforo A.L. Woodcement composites from wastes of Pinus sp. Wood, effect of particles treatment. International, Journal of Composite Materials 4 (2) pp.146-149, (2014)

8. Kh. Kamilov, A. Tulaganov, Adhesion of Mineral Binders with Organic Aggregates, International Journal of Innovative Technology and Exploring Engineering 9 (4) pp 2699-2702. DOI: https://doi.org/10.35940/ijitee.D1886.029420. (2020)

9. Sh.T. Raximov, Resource-saving technology in manufacturing of layer mixtures based on waste industry, European Science Review 1 (2) pp 245-248 (in Austria). (2018)

10. M.V. Kaimonov, Y.A. Khokholov, Selection of Frozen Backfill Mixture Composition, Journal of Mining Science, 55, pp. 857-864, DOI: https://doi.org/10.1134/S1062739119056234. (2019) 
11. U.A. Gaziyev, Technological instruction for the preparation, transportation and laying of filling mixtures using industrial waste, p 8, Uzbekistan, (2016)

12. U.A. Gaziyev, Industrial waste in the production of building materials and products [Text], textbook. Tashkent, p. 308, Uzbekistan, (2015)

13. Patent IAP 06006 Uzbekistan. Backfill mixture to fill the goaf [Text], Gaziyev U. A., Shakirov T.T., Rakhimov Sh.T.; patent holder TIAC. - № IAP 20160080; declaration 09.03.2016, published 20.09.2019. p. 2, Uzbekistan, (2019)

14. USSR Academy of Sciences. Methodical recommendations for quality control of filling mixtures [Text]. M. : Academy of Sciences. p 50. Russia, (1990).

15. GOST 5802_86. Building solutions. Test methods, M.: Standardinform. p. 18. Russia, (2018). 